\title{
FROM REGULARITIES TO NORMS IN THE SECONDARY FORMATION OF ROMANIAN ICT TERMS
}

\author{
Sorina Postolea \\ Alexandru Ioan Cuza University of Iaşi
}

\begin{abstract}
Starting from a parallel corpus of general use texts, this article investigates what kind of regularities are discernible in the formation of the terms used in the Romanian language of information and communication technology (ICT). After a brief presentation of the corpus that supported this research, the article begins with an introduction to the distinction made between the processes of primary and secondary term formation and considers it in relation to the concepts of translation regularities and norms as theorized by Gideon Toury. Starting from a concise examination of the sentence-based turn in translation studies, the final part of the article analyzes the main strategies used in the secondary formation of Romanian ICT terms (borrowing, loan translation, hybrid formation, and translation proper) and attempts to determine which of them could be seen as regularities that ampler studies could confirm as norms in this process.
\end{abstract}

Keywords: terminology, term formation, borrowing, loan translation, corpus

\section{Corpus size and structure}

The analysis carried out in this article is based on a corpus that includes 37 pairs of parallel texts (source English texts and their Romanian translations) ${ }^{1}$ belonging to three general use textual genres frequently employed in the field of information and communication technology (ICT): news articles, press releases, and user manuals. All texts refer to hardware products (laptops, cell phones, various devices and gadgets, peripherals, etc.) and

\footnotetext{
${ }^{1}$ As Bowker \& Pearson have pointed out, "there are no hard and fast rules that can be followed to determine the ideal size of a corpus. Instead, you will have to make this decision based on factors such as the needs of your project, the availability of data and the amount of time that you have $(2002,45)$.
} 
general ICT-relevant technologies, and they were produced and published from September to November 2010. The procedure used to search and collect them started from target texts, that is, from Romanian translations. For instance, in the case of news articles, we followed the news about hardware products published on the websites of two important online Romanian computer magazines, www.chip.ro and www.computerworld.ro during the time frame specified above; then, when we identified an item that met our topic criterion, we selected a few keywords from it and searched them on Google in English. On average, the source news article, written in English, had been published one to three days before the Romanian translated version. Some were published on the same day.

The following table sums up the main characteristics of the corpus:

Table 1. Corpus size and structure

\begin{tabular}{|c|c|c|c|c|c|}
\hline \multicolumn{6}{|c|}{ TOPIC: hardware products and general technologies } \\
\hline \multicolumn{5}{|c|}{ TIME FRAME: September-November 2010} & \multirow[b]{3}{*}{ Code } \\
\hline \multirow[b]{2}{*}{ TEXT TYPE } & \multicolumn{2}{|c|}{ Size } & \multirow{2}{*}{$\begin{array}{c}\text { Number } \\
\text { of } \\
\text { Text Pairs } \\
\end{array}$} & \multirow[b]{2}{*}{ Target text from } & \\
\hline & $\mathbf{E N}$ & RO & & & \\
\hline User Manuals & 24.348 & 24.783 & 3 & Corporate websites & UM \\
\hline \multirow{2}{*}{ News articles } & 8.926 & 6.633 & 16 & www.chip.ro & CHIP \\
\hline & 3.985 & 3.683 & 8 & www.computerworld.ro & COMP \\
\hline $\begin{array}{l}\text { Press } \\
\text { Releases }\end{array}$ & 5.314 & 5.477 & 10 & Corporate websites & PR \\
\hline CORPUS & 41.943 & 40.576 & 37 & & \\
\hline
\end{tabular}

The parallel text pairs were analysed with a special text analysis tool named ParaConc (Version 1.0, Build 269), a commercial program developed by an American researcher, Michael Barlow. ${ }^{2}$

\section{Primary versus secondary term formation}

Whenever a new concept is born, specialists need to create a term to name it. Sometimes, the new designation ${ }^{3}$ may be the creation of an individual, who is usually the inventor of that concept, sometimes the form of terms is selected from various alternatives by a group of people (a team of

\footnotetext{
${ }^{2}$ Computer programs purposefully designed for the linguistic analysis of corpora are called concordancers or concordance programs. Such a computer tool "allows us to search a corpus and retrieve from it a specific sequence of characters of any length perhaps a word, part of a word, or a phrase" (McEnery \& Hardie 2012, 35).

${ }^{3}$ New terms are sometimes called neonyms (Cabré, Pavel and Rucăreanu) or simply neoterms (ISO 704:2009(E))
} 
researchers, a corporation, a terminological commission, etc.). In order to give a name to a new concept, specialists frequently use the resources of their own language, and the list of those resources is quite comprehensive.

Yet, whatever the setting in which a neoterm emerges, it is acceptable to assume that it is primarily linked to the language in which the concept that it names appeared in the first place. This is a process that specialists call primary term formation. However, being basic units of knowledge, concepts are almost never bound to their place of birth. Packed in their original language, they easily travel across borders and, as a result, they also need to get new identification cards in other idioms. This process is called secondary term formation ${ }^{4}$. This distinction was detailed by J. Humbley and Natalie Kübler in their opening lecture at the $4^{\text {th }}$ Joint Seminar Neology and Specialised Translation organised by CVC and Termisti on April 29, 2011, in Brussels (Humbley and Kübler 2011). Citing Rondeau, the two scholars drew a line between neology of origin (when the new concept is named by its creator in his/her native language) and neology of transfer (when the name given to a concept by its original creator passes from its original language into other idioms).

In the case of the ICT field, with very few exceptions, all the new terms are coined in English. As a result, all the terms belonging to the Romanian language of ICT are created through a process of secondary term formation, which involves various strategies of translation or non-translation (transfer) from English into Romanian ${ }^{5}$. Our article aims to explore what kind of regularities and norms can be discerned in this process.

Within the field of translation studies, the concept of norms has been approached at various levels of analysis. The linguistic approaches to translation were primarily concerned "with the linguistic norms of the two languages, i.e. how to produce utterances and texts that are correct according to the respective rules and norms" and with "the relations and regularities between the two linguistic systems that were discovered on the basis of contrastive analyses" (Schäffner 1999, 2). In textual approaches the focus shifted to the norms that govern the overall transfer of texts from a sourceculture to a target-culture, while descriptive translation studies (DTS), envisaging translational behaviour as a type of social behaviour, understood

${ }^{4}$ The labels primary vs. secondary term formation were put forth by J. Sager (cf. Humbley and Kübler 2011).

${ }^{5}$ This notion of secondariness is also present in the definition given to interlingual translation by Katharina Reiss: "a bilingual mediated process of communication, which ordinarily aims at the production of a TL text that is functionally equivalent to an SL text (2 media: SL and TL+1 medium: the translator, who becomes a secondary sender; thus translating: secondary communication)" (Reiss [1971] 2004, 160) 
norms as "internalised behavioural constraints which embody the values shared by a community" (Schäffner 1999, 4). Although DTS scholars, such as Gideon Toury, Theo Hermans, or Andrew Chesterman, "were first and foremost engaged in the study of literary translation" (Toury 1999, 13), it is our opinion that some of the concepts put forth by this approach to translation could also be useful in the study of specialized translation.

For reasons of space, and due to the relatively small size of our corpus, which does not allow for final generalizations, we are not going to discuss in detail the various types of norms identified in the translation process by various DTS scholars. However, a basic DTS notion that seems to be worth exploring in our case is that of translational "regularities". According to Gideon Toury, these "recurrent patterns" that are the "external evidence" of norms "turn out to be a key notion in descriptive studies into translational behaviour and its results as well" because "it is first and foremost discerned regularities, rather than any of the individual phenomena as such, which would then be explained on the assumption that the behaviour which yielded them was indeed norm-governed (...)" (Toury 1999, 21).

In what regards the secondary formation of ICT terms, the generally held opinion is that the norm that governs their transfer from English into Romanian involves direct transfer procedures, in other words borrowing and calque. Our corpus-based analysis intends to investigate whether this hypothetical norm is confirmed by the regularities found in our parallel texts. However, before going into further details about this process we need to take a look at the main coordinates which guide the translation of units of meaning situated at the level of sentences or below.

\section{Sentence-based translation - the linguistic approach to translation studies}

Within the field of translation studies ${ }^{6}$, some theories relating to translation at word level are linked to the linguistic turn in the discipline as represented by J. C. Catford and Peter Newmark's research, or the studies in comparative stylistics of the Canadian scholars Jean-Paul Vinay and Jean Darbelnet. At the core of their basic tenets lies the "major polar split which has marked the history of western translation theory for two thousand years, between two ways of translating: "literal" and "free" (Hatim and Munday 2004, 11).

For Vinay \& Darbelnet ([1958/1995]2004), "translators can choose from two methods of translating, namely direct, or literal translation and oblique translation" (ibid., 84). In the opinion of the two Canadian scholars, "literal, or word for word, translation is the direct transfer of a SL text into a

${ }^{6}$ For excellent overviews of the history of this discipline, see Munday (2001) or Dimitriu (2002). 
grammatically and idiomatically appropriate TL text in which the translators' task is limited to observing the adherence to the linguistic servitudes of the TL" (ibid., 86). While noting that direct translation reflects "parallel thought processes" that are particularly frequent in textual materials belonging to the fields of science and technology (idem), Vinay \& Darbelnet claim that, on the other hand, oblique translation is usually the proper solution when, "because of structural or metalinguistic differences, certain stylistic effects cannot be transposed into the TL without upsetting the syntactic order, or even the lexis" (ibid., 84). The three main strategies whereby translators may carry out direct translations are, according to Vinay \& Darbelnet, borrowing, calque, and literal translation. We are going to return to these categories later on.

Another translation scholar who pondered upon the literal/free translation dichotomy was J.C. Catford (1965). However, the Scottish linguist added a third criterion to this pair, i.e. the notion of $\operatorname{rank}^{7}$. So, according to this new coordinate, he distinguished between three types of translation: free, word-for-word, and literal translation. For Catford, free translation is not rank-bound; it is always unbound: "equivalences shunt up and down the rank scale, but tend to be at the higher ranks - sometimes between larger units than the sentence" (Catford 1965, 25). The other extreme is word-for-word translation, which is perfectly described by its name. According to Catford, it is a rank-bound translation par excellence, being limited to word-rank. Finally, the third type of translation is literal translation, which "may start, as it were, from a word-for-word translation, but make changes in conformity with TL grammar (e.g. inserting additional words, changing structures at any rank, etc.); this may make it a group-group or clause-clause translation" (ibid., 25).

At this point, we should note that the theoretical systems proposed by these scholars in the 1950s and 60s were severely criticised during the following decades. As Munday notices, in Vinay \& Darbelnet's work "there is no incorporation of higher-level discourse considerations nor a means of discussing the effect the changes might have on the reader" (Munday 2001, 69). In his turn, J.C. Catford was also criticized because his examples were "almost idealized (i.e. invented and not taken from actual translations) and decontextualised" (idem), and because he never analysed texts or went above the sentence level.

Yet, despite criticism and the advent of new trends in the study of translation, which shifted the focus of research on higher units of

\footnotetext{
"A third type of differentiation in translation relates to the rank in a grammatical (or phonological) hierarchy at which translation equivalence is established" (Catford 1965, 24).
} 
meaning/translation (textual, functionalist, pragmatic approaches), the linguistic-literal turn has never been completely forgotten. In the late 1980s and early 1990s, Peter Newmark became one of the most prominent supporters of literal translation, but in his own acceptation of the term. In the chapter Pragmatic Translation and Literalism of his well-known book About translation (1991), the English scholar discusses the idea of literal translation in relation to two distinct factors: pragmatism and referentiality: “«Pragmatic» denotes the reader's or readership's reception of the translation, as opposed to «referential», which denotes the relationship between the translation and the extra-linguistic reality it describes" (Newmark 1991, 116). Thus, he makes a distinction between pragmatic and literal translation. In his opinion, a translation is literal when it focuses on referentiality and aims mainly at being referentially accurate; when it has mainly the readers' interest in mind, a translation is pragmatic; as a result, "in «referential translation» the word order is normal; in "pragmatic» translation it is often upset by particular stresses" (ibid., 121). Another idea which should be retained from Peter Newmark's theoretical system is that, in spite of the other trends that were fashionable at the time (mainly textual and functionalist approaches), when he published this book, he obstinately refused to give up the idea that words are indeed important units of translation: "it is absurd to talk about translating texts rather than words" (ibid., 125).

Of course, just like the other scholars mentioned here, Peter Newmark was criticized "for his strong perspectivism" (Munday 2001, 46). However, like other researchers in this field ${ }^{8}$, we believe that the process of translation should not lose its focus on words, or more precisely, on subsentence units. Such a focus is particularly important in specialised translation, in which terms are the main vehicles of knowledge.

\section{Strategies of secondary term formation in Romanian ICT terminology}

Based on the main tenets of the linguistic turn in translation studies, and on the empirical material provided by our parallel corpus, this part of our article analyzes the main strategies used in the secondary formation of Romanian ICT terms. These strategies could also be seen as regularities that could help us discern the norms that underlie this process. Our hypothesis is that these strategies involve, in an overwhelming proportion, direct /word-rank bound/ referential translation. In fact, researchers in the field of terminology usually

\footnotetext{
${ }^{8}$ See for instance, the bottom-up approach adopted by Mona Baker (In Other Words. A coursebook on translation, 1992). In this first seminal work, she devotes an entire chapter to strategies of translation at word level.
} 
mention borrowing and calque, the two techniques of direct translation put forth by Vinay \& Darbelnet, as the two main categories of secondary term formation strategies?.

\subsection{Borrowing}

In a purely linguistic context, a borrowing is usually, defined as the "adoption of a linguistic expression from one language into another language, usually when no term exists for the new object, concept, or state of affairs" (Bussmann 2006, 139). However, if in linguistics the focus is on borrowings as products, in translation borrowings are seen through the lenses of the process whereby they arrive in a particular language. From this perspective, calling it "the simplest of all translation methods", Vinay \& Darbelnet claim that this strategy is used in order to "overcome a lacuna, usually a metalinguistic one (e.g. a new technical process, an unknown concept)". According to Molina \& Hurtado Albir (2002), in a translationrelated context, borrowing means "to take a word or expression straight from another language" $(2002,510)$. This particular procedure is also called "importation", being defined as "the direct transference of a lexeme, both in meaning and form" (Gómez Capuz 1997, 87). In fact, in our opinion, borrowing should not be seen as translation per se, but as a direct procedure whereby a word/term is brought in a particular language from another language. This is why we prefer to refer to this strategy as a strategy of transfer, and not of translation proper.

In relation to our study, we should also mention another concept related to that of linguistic loan: naturalization. As Newmark (cited in Molina \& Hurtado Albir, 2002, 505) explains, this is a procedure whereby the foreign word is somewhat adapted to the grammatical system of the language of destination. According to this criterion, one may distinguish between "pure" or "full" borrowings and naturalized borrowings. To these two extremes, with direct reference to the specificity of Romanian, we would add an intermediate step, which we would call "integrated borrowings". In this category we include the terms that are still somewhere in between and have not yet found a stable form in Romanian.

A quick search through the top 100 most frequent content words in our Romanian subcorpus revealed that 21 forms of the Romanian terms could be seen as borrowings, belonging to all three categories described above:

${ }^{9}$ Humbley \& Kübler (2011, my translation) mention the following secondary term formation strategies: 1) borrowing or identical form; 2) precise technicalscientific calque; 3) simplified technical-scientific calque; 4) adapted technicalscientific calque; 5) various. 
computerul, clic, computerului, disc, computer, bateriei, video,

$3 D$, reference, $P C$, USB, wireless, $H D$, hard, adaptorul,DVD,

radio, audio, card, discul, $L A N$

However, as this analysis does not seem to be relevant enough, we chose to focus on 10 of the most frequent mono-word terms in our corpus, and processed them with ParaConc in order to see how they were translated into Romanian. These words were: $C D$, computer, DVD, graphics card, hard disk, keyboard, LAN, mouse, screen, and touchpad:

Table 2. Translations of 10 common ICT words

\begin{tabular}{|c|c|c|c|c|c|c|c|c|c|}
\hline & $\begin{array}{l}\text { Freq. } \\
\text { EN }\end{array}$ & $\begin{array}{l}\text { RO } \\
\text { Trans }\end{array}$ & $\begin{array}{l}\text { Freq. } \\
\text { RO }\end{array}$ & $\begin{array}{l}\text { Inflected } \\
\text { forms }\end{array}$ & & $\begin{array}{l}\text { Freq. } \\
\text { EN }\end{array}$ & $\begin{array}{l}\text { RO } \\
\text { Trans }\end{array}$ & $\begin{array}{l}\text { Freq. } \\
\text { RO }\end{array}$ & $\begin{array}{l}\text { Inflected } \\
\text { forms }\end{array}$ \\
\hline CD & 17 & $C D$ & 17 & No & \multirow[t]{3}{*}{ keyboard } & \multirow[t]{3}{*}{39} & tastatură & 35 & Yes \\
\hline \multirow[t]{3}{*}{ computer } & \multirow[t]{3}{*}{292} & computer & 281 & Yes & & & No trans. & 3 & \\
\hline & & calculator & 9 & Yes & & & tastă & 1 & Yes \\
\hline & & $P C$ & 1 & No & \multirow[t]{2}{*}{ LAN } & \multirow[t]{2}{*}{24} & $L A N$ & 23 & No \\
\hline \multirow[t]{2}{*}{ DVD } & \multirow[t]{2}{*}{30} & $D V D$ & 29 & No & & & No trans. & 1 & \\
\hline & & No trans. & 1 & & \multirow[t]{4}{*}{ screen } & \multirow[t]{4}{*}{108} & ecran & 79 & Yes \\
\hline \multirow[t]{2}{*}{$\begin{array}{l}\text { graphics } \\
\text { card }\end{array}$} & \multirow[t]{2}{*}{4} & $\begin{array}{l}\text { placă } \\
\text { grafică }\end{array}$ & 3 & Yes & & & screen & 17 & No \\
\hline & & $\begin{array}{l}\text { placă } \\
\text { video }\end{array}$ & 1 & Yes & & & afişaj & 9 & Yes \\
\hline \multirow[t]{4}{*}{ hard disk } & \multirow[t]{4}{*}{33} & hard disc & 18 & Yes* & & & No trans. & 3 & \\
\hline & & hard disk & 7 & No & \multirow[t]{2}{*}{ mouse } & \multirow[t]{2}{*}{11} & mouse & 5 & Yes*** \\
\hline & & hardisk & 5 & Yes** & & & maus & 6 & Yes \\
\hline & & $\begin{array}{l}\text { unitate de } \\
\text { disc }\end{array}$ & 3 & Yes & touchpad & 15 & $\begin{array}{l}\text { zonă de } \\
\text { atingere }\end{array}$ & 15 & Yes \\
\hline
\end{tabular}

*one instance with dash - hard disc-ul; ** with dash - hardisk-uri;

*** with dash - mouse-ului;

This brief screening of the material included in our corpus allowed us to draw the following provisional conclusions in what regards the use of borrowing in the secondary term formation of Romanian ICT terms:

a) initialisms seem to be the only terminological units which are almost exclusively borrowed; in our corpus we found no integrated/naturalised initialisms, although such forms exist;

b) only four terms (computer, hard disk, mouse, and screen) have been introduced into Romanian through borrowing, and their loaned version is not the only one available. This is the case of computer; this naturalised loan (computerul), co-exists with its translation, calculator, although the borrowing is much more frequent. In one instance, it was replaced in translation by an initialism, $P C$, which is also a borrowing. The case of hard disk is very interesting, as it has been introduced into Romanian in all possible forms: as a full borrowing (non inflected hard disk), as a naturalised borrowing (hard disc, with one instance in which it was rather integrated 
hard disc-ului), as an integrated clipped form (hardisk), and as a loan translation (unitate de disc). Screen has two indigenous counterparts (ecran and afişaj - which is rather the translation of display), but still functions as a full borrowing sometimes. Finally, Romanian seems to have solved the difficulties related to the naturalisation of mouse, as a new, fully naturalised version of this term seems to be emerging: maus (in fact, a Romanian spelling for the pronunciation of the English word);

c) there is still a great amount of uncertainty in what regards borrowings in this field of activity, naturalised forms coexisting with full loan forms and integrated borrowings;

d) another interesting provisional conclusion is that, in spite of the general assumption, borrowings are not so frequent after all in the Romanian language of ICT, as they represent only about $20 \%$ of the top 100 most frequent content words in our Romanian sub-corpus. However, this is a hypothesis which deserves further investigation, on a much larger scale.

\subsection{Loan translation}

The most prolific secondary term formation strategy seems to be loan translation or calque. This is the other technique put by Vinay \& Darbelnet under the umbrella of direct translation. For the two authors, "a calque is a special kind of borrowing whereby a language borrows an expression form of another, but then translates literally each of its elements (85). However, for Molina \& Hurtado Albir (2002, 510), a calque is the "literal translation of a foreign word or phrase", which can be "lexical or structural". Yet, a more detailed description is provided by the Routledge Dictionary of Language and Linguistics (Bussmann 2006, 151): "While, in the case of borrowing, a foreign word and its meaning are adopted wholesale into the other language as a loan word, a calque emerges when the language is adapted to new concepts. This can happen in several ways: (a) by way of a borrowed meaning through change and expansion of the meaning of native words; (b) through neologisms loosely based on a foreign concept; (c) through wordfor-word loan translation; (d) through a loose loan translation".

With these considerations in mind, we shall attempt to sketch a brief classification of the types of loan translations specific to the Romanian language of ICT. To this purpose, our analysis is based on the most frequent collocations of the 10 sample mono-word terms specified above and their translations, as they were displayed by our parallel concordancer, ParaConc.

Table 3. Collocations of 10 sample terms and their translation into Romanian 


\begin{tabular}{|c|c|c|c|c|c|c|c|}
\hline Term/Collocation & Fr. & Translation & Fr. & Term/Collocation & Fr. & Translation & Fr. \\
\hline \multicolumn{4}{|c|}{ screen } & \multicolumn{4}{|c|}{ keyboard } \\
\hline \multirow[t]{5}{*}{ TV screen } & 11 & televizor & 1 & keyboard port & 1 & $\begin{array}{ll}\text { port } & \mathrm{de} \\
\text { tastatură } & \\
\end{array}$ & 1 \\
\hline & & ecran TV & 2 & QUERTY keyboard & 3 & $\begin{array}{l}\text { tastatură } \\
\text { QUERTY } \\
\end{array}$ & 2 \\
\hline & & $\begin{array}{l}\text { ecranul } \\
\text { televizorului }\end{array}$ & 4 & external keyboard & 3 & $\begin{array}{l}\text { tastatură } \\
\text { externă }\end{array}$ & 3 \\
\hline & & afişaj & 1 & backlit keyboard & 2 & $\begin{array}{l}\text { tastatură } \\
\text { iluminată } \\
\text { din spate }\end{array}$ & 1 \\
\hline & & ecran & 2 & physical keyboard & 1 & tastatură & 1 \\
\hline boot screen & 4 & $\begin{array}{l}\text { ecran de boot- } \\
\text { are }\end{array}$ & 4 & $\begin{array}{l}\text { internal keyboard } \\
\text { cable }\end{array}$ & 1 & $\begin{array}{l}\text { cablul } \\
\text { tastaturii }\end{array}$ & 1 \\
\hline touch screen & 3 & touch screen & 3 & \multicolumn{4}{|c|}{ LAN } \\
\hline \multirow[t]{3}{*}{ touchscreen } & 12 & ecran tactil & 5 & \multirow[t]{5}{*}{ wireless LAN } & 14 & LAN fără fir & 1 \\
\hline & & ecran & 1 & & & $\begin{array}{l}\text { wireless } \\
\text { LAN }\end{array}$ & 2 \\
\hline & & touchscreen & 3 & & & $\begin{array}{l}\text { rețea LAN } \\
\text { fără fir }\end{array}$ & 6 \\
\hline display screen & 1 & ecran de afişaj & & & & $\begin{array}{l}\text { modul LAN } \\
\text { wireless }\end{array}$ & 1 \\
\hline screen saver mode & 1 & $\begin{array}{l}\text { modul screen } \\
\text { saver }\end{array}$ & 1 & & & $\begin{array}{l}\text { capacitate } \\
\text { LAN } \\
\text { wireless }\end{array}$ & 1 \\
\hline \multirow[t]{2}{*}{ screen brightness } & 3 & $\begin{array}{l}\text { luminozitatea } \\
\text { ecranului }\end{array}$ & 2 & LAN port & 3 & port LAN & 3 \\
\hline & & $\begin{array}{l}\text { luminozitatea } \\
\text { afişajului }\end{array}$ & 1 & $\begin{array}{l}\text { wireless LAN } \\
\text { antenna }\end{array}$ & 1 & $\begin{array}{l}\text { antenă rețea } \\
\text { LAN fără fir }\end{array}$ & 1 \\
\hline offscreen & 1 & offscreen & 1 & $\begin{array}{l}\text { wireless LAN Mini } \\
\text { PC Card }\end{array}$ & 1 & $\begin{array}{lr}\text { Card } & \text { PC } \\
\text { LAN } & \text { Mini } \\
\text { wireless }\end{array}$ & 1 \\
\hline \multirow[t]{2}{*}{ on-screen } & 7 & $\begin{array}{l}\text { cu afişare pe } \\
\text { ecran }\end{array}$ & 2 & \multicolumn{4}{|c|}{ mouse } \\
\hline & & (de) pe ecran & 3 & external mouse & 2 & $\begin{array}{l}\text { mouse } \\
\text { extern }\end{array}$ & 2 \\
\hline widescreen & 3 & $\begin{array}{l}\text { ecran } \\
\text { panoramic }\end{array}$ & 3 & \multicolumn{4}{|c|}{ touchpad } \\
\hline widescreen format & 1 & $\begin{array}{l}\text { format } \\
\text { panoramic }\end{array}$ & 1 & built-in touchpad & 1 & $\begin{array}{l}\text { zonă } \quad \text { de } \\
\text { atingere } \\
\text { încorporată }\end{array}$ & 1 \\
\hline \multicolumn{4}{|c|}{ CD } & internal touchpad & 1 & $\begin{array}{ll}\begin{array}{l}\text { zonă } \\
\text { atingere }\end{array} & \text { de } \\
\end{array}$ & 1 \\
\hline CD/DVD drive & 3 & $\begin{array}{l}\text { unitate } \\
\text { CD/DVD }\end{array}$ & 3 & \multicolumn{4}{|c|}{ hard disk } \\
\hline \multicolumn{4}{|c|}{ computer } & hard disk drive & 4 & $\begin{array}{l}\text { unitatea hard } \\
\text { disc }\end{array}$ & 1 \\
\hline personal computer & 14 & $\begin{array}{l}\text { computer } \\
\text { personal }\end{array}$ & 14 & & & $\begin{array}{ll}\text { unitatea de } \\
\text { hard disk }\end{array}$ & 1 \\
\hline handheld computer & 12 & $\begin{array}{l}\text { computer } \\
\text { portabil }\end{array}$ & 12 & & & $\begin{array}{ll}\text { hard } & \text { disk } \\
\text { drive } & \\
\end{array}$ & 2 \\
\hline
\end{tabular}




\begin{tabular}{|l|l|l|l|l|l|l|l|}
\hline $\begin{array}{l}\text { computer security } \\
\text { lock }\end{array}$ & 6 & $\begin{array}{l}\text { blocaj de } \\
\text { securitate al } \\
\text { computerului }\end{array}$ & 6 & $\begin{array}{l}\text { hard disk drive } \\
\text { indicator }\end{array}$ & 3 & $\begin{array}{l}\text { indicatorul } \\
\text { unității hard } \\
\text { disc }\end{array}$ & 1 \\
\hline \multicolumn{3}{|c|}{ DVD } & & & $\begin{array}{l}\text { indicatorul } \\
\text { pentru } \\
\text { unitate hard } \\
\text { disc }\end{array}$ & 2 \\
\hline DVD disc & 10 & disc DVD & 10 & $\begin{array}{l}\text { external multimedia } \\
\text { hard disk drive }\end{array}$ & 1 & $\begin{array}{l}\text { hardisk } \\
\text { multimedia } \\
\text { extern }\end{array}$ & 1 \\
\hline DVD player & 4 & $\begin{array}{l}\text { DVD } \\
\text { player(ul })\end{array}$ & 3 & $\begin{array}{l}\text { multimedia hard } \\
\text { disk drive }\end{array}$ & 1 & $\begin{array}{l}\text { hardisk } \\
\text { multimedia }\end{array}$ & 1 \\
\hline
\end{tabular}

There are several available classifications of loan translations, but here we are going to use the taxonomies put forth by Gómez Capuz (1997) and Di Spaldro (2007).

\subsubsection{Semantic borrowing}

Both authors talk about this phenomenon, which, in plain words, is the simplest form of loan translation. It is usually carried out at word level. "Semantic borrowing implies the transference of a semene or unity of meaning" (Gómez Capuz 1997, 86). Di Spaldro, apud Loubier (2007, 13), calls this procedure false borrowing. It is the process whereby the native words of a language receive new meanings, which, in our case, are specialised meanings. In the Romanian language of ICT such new meanings may be identified in terms like: afişaj, disc (two meanings in compact disc and in hard disc), panoramic, port, or tactil.

\subsubsection{Loan translation proper}

For Gómez Capuz $(1997,89)$, it is "an exact loan translation, not only in meaning but also in structure". His definition actually includes two types of calques put forth by Di Spaldro under the category of morphological loan translations: (non adapted) literal calque and adapted literal calque (2007, 14). The former "reproduces exactly the foreign morpho-syntactic model" (my translation) while the latter adapts this model to the structure of the target language. According to Di Spaldro, adapted literal calque is the most frequent type of loan translation in scientific and technical fields.

- literal calques: not present in our present sample list ${ }^{10}$

\footnotetext{
${ }^{10}$ We could argue that forms such as unitate hard disc, disc DVD or port LAN are a type of literal calque. Although they follow the proper Romanian word order, they are formed by juxtaposition, which is a rather unusual term-formation technique for the target language.
} 
- adapted literal calques: tastatură externă, zonă de atingere încorporată, ecran de afişaj, luminozitatea ecranului, ecran panoramic

\subsubsection{Loan rendition}

According to Gómez Capuz (1997, 89), loan rendition is an approximate loan translation. This category coincides with what Di Spaldro calls adapted calque, which is a "translation that is not produced by pure imitation but by a more or less significant adaptation of the foreign morpho-syntactic model to that of the target language" (Loubier, cited in Di Spaldro 2007, 14, my translation).

For Gómez Capuz $(1997,89)$, there are three types of loan renditions:

- asymmetric loan translations: indicatorul unităţii hard disc

- contracted loan translations: cablul tastaturii < internal keyboard cable; tastatură < physical keyboard,

- expanded loan translations: tastatură iluminată din spate < backlit keyboard, cu afişare pe ecran < on-screen

\subsection{Hybrid formation}

In our classification of calques we have deliberately omitted a series of terms which are quite frequent in the language of ICT. We call them hybrid terms and we define them as terminological units which are formed in a secondary language by both borrowing and loan translation. Being somewhere in between the types of terms described above, hybrid terms may be classified according to similar criteria.

According to the loan word occurring in their structure, they may be:

- integrated: ecran de boot-are, unitatea de hard disk, DVD player(ul)

- $\quad$ naturalised: computer personal, disc DVD

According to the process involved in their translation, they may be:

- literal hybrid terms/loans: DVD player

- $\quad$ adapted hybrid terms: unitate CD/DVD, computer portabil, unitatea de hard disk, modul screen saver

- contracted hybrid terms: hardisk multimedia extern < external multimedia hard disk drive

- expanded hybrid terms: rețea LAN fără fir < wireless LAN 4.4. Translations proper

The final strategy used in the secondary term formation of Romanian ICT terms is translation proper, and it is mainly carried out in the case of complex terminological units. The test screening of our corpus revealed three units of this kind: 
(EN) handheld computer incorporating wireless WAN modem

(RO) computer portabil care încorporează un modem pentru reţea WAN fără fir

(EN) vibration dampened hard disk drive

(RO) hard disk drive cu amortizor de vibraţii

(EN) single-chip widescreen capacitive touchscreen controller

(RO) controler pentru touchscreen-uri capacitive

In the first example, the Romanian version uses explicitation to clarify the meaning of WAN; the second example uses transposition (vibration dampened > amortizor de vibratii), while the last example is a contraction.

\section{Conclusions}

This article aimed to explore from a translational perspective the main regularities discernable in the secondary formation of Romanian ICT terms. Based on the empirical material provided by our general use parallel corpus and on several theoretical perspectives, we were able to identify four main strategies of transfer/translation at term level: borrowing, loan translation/calque, hybrid formation and translation proper. Our data seem to confirm our initial hypothesis, namely that direct /word-rank bound/ referential translation is the tool of choice in the translation of these terms. However, contrary to the general opinion, it seems that loan translation and not borrowing is the preferred norm for secondary term formation in the Romanian language of ICT. Further studies are needed to confirm whether the regularities discerned by this small-scale analysis could gain the status of norms in this process.

\section{Works Cited}

***. 2009. "ISO 704:2009(E). Terminology work - Principles and methods." International Standard Organisation.

Baker, Mona. In Other Words. A coursebook on translation. London and New York: Routledge. 1992. Print.

Bowker, Lynne and Jennifer Pearson. Working with Specialized Language: a Practical Guide to Using Corpora. London and New York: Routledge. 2002. Print.

Bussmann, Hadumod. Routledge Dictionary of Language and Linguistics. Gregory Trauth and Kerstin Kazzazi (eds.). Translated by Gregory Trauth and Kerstin Kazzazi. London and New York: Routledge. 2006. Print. 
Cabré, Maria Teresa. Terminology. Theory, Methods and Applications. Juan C. Sager (ed.). Translated by Janet Ann DeCesaris. Amsterdam/Philadelphia: John Benjamins. 1999. Print.

Catford, J. C. A Linguistic Theory of Translation. An Essay in Applied Linguistics. Oxford: Oxford University Press. 1965.Print.

Di Spaldro, Josée. "Les calques technoscientifiques en situation d'aménagement terminologique québécois." Les Journées de Linguistique. Actes du XXIe Colloque. Adèle St-Pierre and Mélanie Thibeault (eds.). Laval: Centre interdisciplinaire de recherches sur les activités langagières, Université de Laval. 2007. 12-25. Print.

Dimitriu, Rodica. Theories and Practice of Translation. Iaşi: Institutul European. 2002. Print.

Gómez Capuz, Juan. "Towards a Typological Classification of Linguistic Borrowing (Illustrated with Anglicisms in Romance Languages)". Revista Alicantina de Estudios Ingleses 10 (1997) .81-94. Print.

Gómez González-Jover, Adelina. "Léxico especializado y traducción.” Las lenguas profesionales y académicas. Enrique Alcaraz-Varó, José Mateo Martinez and Francisco Yus Ramos. (eds.) Barcelona: Editorial Ariel. 2007. .27-40. Print.

Hatim, Basil and Jeremy Munday. Translation. An Advanced Resource Book. London and New York: Routledge. 2004. Print.

Humbley, John and Natalie Kübler. "Néologie d'origine, néologie de transfert: à la recherche d'une complémentarité." Neology and Specialised Translation. 4th Joint Seminar organised by CVC and Termisti. Brussels: 29 April 2011 [personal notes].

McEnery, Tony and Andrew Hardie. Corpus Linguistics: Method, Theory and Practice. Cambridge: Cambridge University Press. 2012. Print.

Molina, Lucía and Amparo Hurtado Albir.. "Translation Techniques Revisited: A Dynamic and Functionalist Approach." Meta: journal des traducteurs / Meta: Translators' Journal 47, 4 ( 2002). 498-512. Print.

Munday, Jeremy. Introducing Translation Studies. Theories and applications. London and New York: Routledge. 2001. Print.

Newmark, Peter. About Translation. Clevedon Philadelphia Adelaide: Multilingual Matters. 1991. Print.

Palacios, Joaquín García and Lara Sanz Vicente. "The role of translation in secondary term formation." Neology and Specialised Translation. 4th Joint Seminar organised by CVC and Temisti. Brussels: 29 April 2011 [personal notes].

Pavel, Eugeniu and Costin Rucăreanu.. Introducere în terminologie. Noțiuni fundamentale. Bucureşti: Editura Academiei Române, Editura Agir. 2001. Print.

Pearson, Jennifer. Terms in Context. Amsterdam / Philadelphia: John Benjamins Publishing Company. 1998. Print.

Reiss, Katharina. "Type, kind and individuality of text. Decision making in translation." The Translation Studies Reader. Lawrence Venuti (ed.). Translated by Susan Kitron. Taylor \& Francis e-Library. London and New York: Routledge. [1971] 2004 160-172. Print. 
Schäffner, Christina. "The Concept of Norms in Translation Studies." Translation and Norms. Christina Schäffner (ed.). Clevedon/Philadelphia 1999.1-9. Print.

Vinay, Jean-Paul and Jean Darbelnet. "A methodology for translation." The Translation Studies Reader. Lawrence Venuti (ed.). Translated by Juan C. Sager and M.-J. Hamel. Taylor \& Francis e-Library. London and New York: Routledge. [1958/1995] 2004. 84-93. 